\title{
Analysis and Design of Decision Support System Information Systems in Choosing the Best Supplier Using the TOPSIS Method at PT. Bintang Putra Mandiri
}

\author{
Kelvin Tri Tama ${ }^{1}$, Andi Leo ${ }^{2}$, \\ 1, 2 University Buddhi Dharma, Information Systems, Banten, Indonesia
}

\begin{tabular}{|c|c|}
\hline SUBMISSION TRACK & A B S T R A C $\mathbf{T}$ \\
\hline $\begin{array}{l}\text { Received } 20 \text { June } 2019 ; \\
\text { Revised } 20 \text { July } 2019 ; \\
\text { Accepted } 10 \text { September 2019; } \\
\text { Available online } 20 \text { September } 2019\end{array}$ & \multirow{6}{*}{$\begin{array}{l}\text { Analysis and design of a decision support system aims to } \\
\text { deal with problems in selecting the best supplier which is a } \\
\text { problem at PT. Independent male star. PT. Bintang Putra } \\
\text { Mandiri is a company engaged in the subsidized housing } \\
\text { contractor and developer. With the existing problems, we } \\
\text { need a system that can help companies to help determine the } \\
\text { best supplier. Then produced a system that can help } \\
\text { companies by using the TOPSIS method. TOPSIS uses the } \\
\text { principle that the chosen alternative must have the shortest } \\
\text { distance from the positive ideal solution and the farthest } \\
\text { distance from the negative ideal solution from a geometric } \\
\text { point of view using the Euclidean distance to determine the } \\
\text { relative proximity of an alternative to the optimal solution. } \\
\text { As a result, PT. Bintang Putra Mandiri can determine the } \\
\text { best supplier precisely. And the TOPSIS method is able to } \\
\text { support supplier selection decisions by ranking }\end{array}$} \\
\hline KEYWORD & \\
\hline $\begin{array}{l}\text { Analysis, Design, Information Systems, } \\
\text { Decision Support Systems, Suppliers, TOPSIS }\end{array}$ & \\
\hline KORESPONDENSI & \\
\hline E-mail: kelvintritama21@gmail.com & \\
\hline Andileo6205@gmail,com & \\
\hline
\end{tabular}

\section{INTRODUCTION}

Technology and information systems have become daily food in human life. Very rapid development has a very important role in the progress of business or daily life. In our lives many problems that encourage us to make the best decisions to solve problems. This is also the case with companies that make decisions every day. With that decision support requires information technology, due to changes in the era of companies competing to be the foremost, which requires companies to move quickly in making decisions. With reference to the solutions provided by the TOPSIS method (Technique For Order Preference by Similiarty to Ideal Solution).

\section{LITERATURES REVIEW}

In Journal [1] Evaluation of lecturers' performance in teaching using the TOPSIS method can provide a more precise level of accuracy. 
In Journal [2] Based on the results of the study it can be concluded that there are 2 healthy home conditions and 8 unhealthy home conditions; The TOPSIS method can be applied to determine the priority of an unhealthy home which results in the second alternative on behalf of (Sutardi) with a preference value (1) expressed as a top priority for the condition of an unhealthy home; The results of the system calculation have been validated with manual calculations and the same results are obtained, and it can be said that the system that has applied the TOPSIS method to determine the priority of unhealthy houses has been going well and accordingly.

In Journal [3] Can Solve the Problems of Obese People. Where in this decision making. Use the TOPSIS method which will help the alternative selection process

\section{TOPSIS}

The Technical Method for Preference Ordering based on Similarity with Ideal Solutions (TOPSIS) is one of the multicriteria decision making methods first introduced by Yoon and Hwang (1981). TOPSIS uses the principle that the chosen alternative must have the shortest distance from the positive ideal solution and the farthest distance from the negative ideal solution from a geometric point of view using the Euclidean distance to determine the relative proximity of an alternative to the optimal solution. The positive ideal solution is defined as the worst achieved for each attribute. TOPSIS considers both the distance to a positive ideal solution and the distance to a negative ideal solution by taking a closeness relative to a positive ideal solution. [4]

\section{Decision Support System}

"Decision Support System (SPK) is a computer-based interactive application that combines data and mathematical models to help the decision making process in handling a problem." [5]

\section{Supplier}

"Suppliers are part of the supply chain that affects the survival of a company. Quality, flexibility, product diversity, fast response, and competition in the global environment are important for companies to obtain customer satisfaction. "[6]

\section{METHODS}

Technique For Order Performance by Similarity to Ideal Solution

Steps in TOPSIS:

1. Determine the normalized decision matrix

$$
r i j=\frac{X i j}{\sqrt{\sum_{\mathrm{j}=1}^{\mathrm{J}} \mathrm{X}_{\mathrm{ij}}^{2}}}, \mathrm{j}=1,2,3 \ldots, \mathrm{J} ; \mathrm{i}=1,2,3, \ldots, \mathrm{n}
$$

Information:

$\mathrm{Xij}$ is the value of real data

$\mathrm{Rij}$ is an element of a normalized decision matrix.

2. Determine the normal weight Vij value based on the value of the Rij multiplication matrix with $\mathrm{Wij}$.

$\mathrm{Vij}=\mathrm{Wj} * \mathrm{rij}$

Information :

$\mathrm{Wj}$ is the weighting of the criteria

$\mathrm{Vij}$ is an element of a weighted, numeralized decision matrix.

3. Determine Positive Ideal Value Solution (PIS) and Negative Ideal Value Solution (NIS)

$\mathrm{A}^{*}=\{\mathrm{V} 1 *, \mathrm{~V} 2 *, \ldots ., \mathrm{Vn} *\}$

$\mathrm{A}-=\{\mathrm{V} 1-, \mathrm{V} 2-, \ldots ., \mathrm{Vn}-\}$ 
4. Calculating the Distance Value of each alternative based on the value of the PIS and NIS.

$$
\begin{gathered}
d_{i}^{+}=\sqrt{\sum_{j=1}^{n}\left(v_{i j}-v_{j}^{+}\right)^{2}, j=1,2, \ldots, J} \\
d_{i}^{-}=\sqrt{\sum_{j=1}^{n}\left(v_{i j}-v_{j}^{-}\right)^{2}, j=1,2, \ldots, J}
\end{gathered}
$$

Information :

$\mathrm{Vj}+$ is a positive ideal solution matrix

$\mathrm{Vj}$ - is the ideal negative solution matrix

5. Calculating the closest value (Closeness Coefficient) based on the ideal value of each alternative

$$
C C_{i}=\frac{d_{i}^{-}}{d_{i}^{+}+d_{i}^{-}}, i=1,2, \ldots \ldots, j
$$

Information :

a greater ci value indicates alternative priority.

\section{RESULT}

The criteria used are as follows: Appropriate Goods, Price, Delivery Time, Service, Quality.

Table 1 Rating Weight

\begin{tabular}{|r|l|}
\hline Weight & Right Item \\
\hline 1 & Very Inaccurate \\
\hline 2 & Not exactly \\
\hline 3 & Right enough \\
\hline 4 & Right \\
\hline 5 & Very precise \\
\hline
\end{tabular}

The table above is a ranking assessment for each criterion
Table 2 Analysis results

\begin{tabular}{|l|l|l|l|l|l|}
\hline Supplier & Price & $\begin{array}{l}\text { Right } \\
\text { Item }\end{array}$ & $\begin{array}{l}\text { delivery } \\
\text { time }\end{array}$ & Quality & Service \\
\hline PT.SMW & 5 & 5 & 5 & 4 & 4 \\
\hline PT.SBL & 4 & 4 & 5 & 4 & 4 \\
\hline Bos Baja & 2 & 4 & 4 & 4 & 4 \\
\hline $\begin{array}{l}\text { Trimulia } \\
\text { Kencana } \\
\text { Baja }\end{array}$ & 3 & 4 & 4 & 4 & 3 \\
\hline
\end{tabular}

The criteria are assessed from the assessment weight table.

Tabel 3 Normalization

\begin{tabular}{|l|l|l|l|l|l|}
\hline $\begin{array}{l}\text { Supp } \\
\text { lier }\end{array}$ & Price & $\begin{array}{l}\text { Right } \\
\text { Item }\end{array}$ & $\begin{array}{l}\text { deliver } \\
\text { y time }\end{array}$ & $\begin{array}{l}\text { Qua } \\
\text { lity }\end{array}$ & Service \\
\hline PT.S & 0,68041 & 0,58520 & 0,55215 & & 0,52981 \\
MW & 3817 & 5736 & 763 & 0,5 & 2943 \\
\hline PT.S & 0,54433 & 0,46816 & 0,55215 & & 0,52981 \\
BL & 1054 & 4589 & 763 & 0,5 & 2943 \\
\hline Bos & 0,27216 & 0,46816 & 0,44172 & & 0,52981 \\
Baja & 5527 & 4589 & 6104 & 0,5 & 2943 \\
\hline Trim & & & & & \\
ulia & & & & & \\
Kenc & & & & & \\
ana & 0,40824 & 0,46816 & 0,44172 & & 0,39735 \\
Baja & 829 & 4589 & 6104 & 0,5 & 9707 \\
\hline
\end{tabular}

Squaring each element of the matrix for example for PT.SMW which has a value of 5 squared to be $5 \wedge 5=25$. The total row is obtained by adding up each row on each criterion. For example the total column Price $25+16+4+9=54$. And to get the normalization value is 5 divided by the square root of 54 the result is 0.680413817

Table 4 Weighted Normalization

\begin{tabular}{|l|l|l|l|l|l|}
\hline $\begin{array}{l}\text { Supp } \\
\text { lier }\end{array}$ & Price & $\begin{array}{l}\text { Right } \\
\text { Item }\end{array}$ & $\begin{array}{l}\text { deliver } \\
\text { y time }\end{array}$ & $\begin{array}{l}\text { Qua } \\
\text { lity }\end{array}$ & Service \\
\hline PT.S & 3,40206 & 1,75561 & 2,20863 & & 1,05962 \\
MW & 9087 & 7208 & 0521 & 2,5 & 5886 \\
\hline PT.S & 2,72165 & 1,40449 & 2,20863 & & 1,05962 \\
BL & 527 & 3766 & 0521 & 2,5 & 5886 \\
\hline Bos & 1,36082 & 1,40449 & 1,76690 & & 1,05962 \\
Baja & 7635 & 3766 & 4417 & 2,5 & 5886 \\
\hline Trim & & & & & \\
ulia & & & & & \\
Kenc & & & & & \\
ana & 2,04124 & 1,40449 & 1,76690 & & 0,79471 \\
Baja & 1452 & 3766 & 4417 & 2,5 & 9414 \\
\hline
\end{tabular}

Settlement: Price obtained from calculation $[0.680413817 * 5]=3.402069087$ 
Table 5 The Ideal Solution Matrix

\begin{tabular}{|l|l|l|l|l|l|}
\hline & Price & $\begin{array}{l}\text { Right } \\
\text { Item }\end{array}$ & $\begin{array}{l}\text { deliver } \\
\text { y time }\end{array}$ & $\begin{array}{l}\text { Qua } \\
\text { lity }\end{array}$ & Service \\
\hline positi & 3,40206 & 1,75561 & 2,20863 & & 1,05962 \\
ve & 9087 & 7208 & 0521 & 2,5 & 5886 \\
\hline $\begin{array}{l}\text { Nega } \\
\text { tive }\end{array}$ & 1,36082 & 1,40449 & 1,76690 & & 0,79471 \\
\hline
\end{tabular}

The ideal solution matrix is obtained based on weighted normalization. The positive ideal solution is to take the maximum value from weighted normalization. Instead the negative ideal solution is taken the minimum value of weighted normalization.

Table 6 Ideal Positive Distance Solution

\begin{tabular}{|l|l|l|l|l|l|l|}
\hline $\begin{array}{l}\text { Sup } \\
\text { plie } \\
\text { r }\end{array}$ & Price & $\begin{array}{l}\text { Right } \\
\text { Item }\end{array}$ & $\begin{array}{l}\text { delive } \\
\text { ry } \\
\text { time }\end{array}$ & $\begin{array}{l}\text { Qu } \\
\text { alit } \\
\text { y }\end{array}$ & $\begin{array}{l}\text { Servi } \\
\text { ce }\end{array}$ & Price \\
\hline PT. & & & & & & \\
SM & & & & 0 & 0 & $\mathbf{0}$ \\
W & 0 & 0 & 0 & 0 & & $\mathbf{0 , 7 6 5}$ \\
& 0,462 & 0,123 & & & & $\mathbf{6 7 0 0 5}$ \\
PT. & 96296 & 28767 & & & 0 & $\mathbf{6}$ \\
SBL & 3 & 1 & 0 & 0 & 0 & \\
\hline & 4,166 & 0,123 & 0,195 & & & $\mathbf{2 , 1 1 7}$ \\
Bos & 66666 & 28767 & 12195 & & & $\mathbf{7 9 9 8 7}$ \\
Baja & 7 & 1 & 1 & 0 & 0 & \\
\hline Tri & & & & & & \\
muli & & & & & & \\
a & & & & & 0,070 & \\
Ken & 1,851 & 0,123 & 0,195 & & 17543 & $\mathbf{1 , 4 9 6}$ \\
cana & 85185 & 28767 & 12195 & & 9 & $\mathbf{8 0 8 9 1}$ \\
Baja & 2 & 1 & 1 & 0 & 9 \\
\hline
\end{tabular}

Weighted normalization minus the positive ideal solution matrix then rank 2 $3.402069087-3.402069087 \wedge 2=0$. And so on if it's past the total then at the root

Table 7 Ideal Negative Distance Solution

\begin{tabular}{|l|l|l|l|l|l|l|}
\hline $\begin{array}{l}\text { Sup } \\
\text { plie } \\
\text { r }\end{array}$ & Price & $\begin{array}{l}\text { Right } \\
\text { Item }\end{array}$ & $\begin{array}{l}\text { delive } \\
\text { ry } \\
\text { time }\end{array}$ & $\begin{array}{l}\text { Qu } \\
\text { alit } \\
\text { y }\end{array}$ & $\begin{array}{l}\text { Servi } \\
\text { ce }\end{array}$ & Price \\
\hline PT. & 4,166 & 0,123 & 0,195 & & 0,070 & \\
SM & 66666 & 28767 & 12195 & & 17543 & $\mathbf{2 , 1 3 4}$ \\
W & 7 & 1 & 1 & 0 & 9 & $\mathbf{3 0 3 5 7}$ \\
\hline & 1,851 & & 0,195 & & 0,070 & $\mathbf{1 , 4 5 5}$ \\
PT. & 85185 & & 12195 & & 17543 & $\mathbf{0 4 2 6 9}$ \\
SBL & 2 & 0 & 1 & 0 & 9 & $\mathbf{4}$ \\
\hline & & & & & 0,070 & $\mathbf{0 , 2 6 4}$ \\
Bos & & & & & 17543 & $\mathbf{9 0 6 4 7}$ \\
Baja & 0 & 0 & 0 & 0 & 9 & $\mathbf{1}$ \\
\hline
\end{tabular}

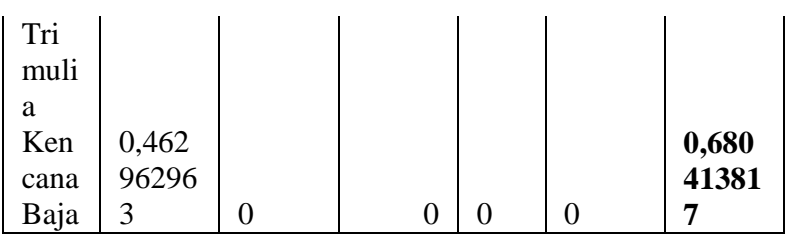

Weighted normalization minus the negative solution matrix and then rank 2.3.402069087-1.360827635 ^ $2=$ 4.166666667. And so on if it's been in total then in the root.

Table 8 Preference

\begin{tabular}{|l|r|r|r|r|}
\hline Supplier & Positive & Negative & Preference & $\begin{array}{l}\text { Ran } \\
\text { k }\end{array}$ \\
\hline PT.SM & & 2,1343035 & & \\
W & 0 & 7 & 1 & $\mathbf{1}$ \\
\hline & 0,7656700 & 1,4550426 & 0,6552142 & \\
PT.SBL & 56 & 94 & 75 & $\mathbf{2}$ \\
\hline Bos & 2,1177998 & 0,2649064 & 0,1111788 & \\
Baja & 7 & 71 & 17 & $\mathbf{4}$ \\
\hline Trimuli & & & & \\
a & & & & \\
Kencan & 1,4968089 & 0,6804138 & 0,3125145 & \\
a Baja & 1 & 17 & 67 & $\mathbf{3}$ \\
\hline \multicolumn{5}{|r|}{}
\end{tabular}

Preference is obtained from the division of negative ideals divided by the sum of positive and negative ideals. Based on the formula above, the following example is calculated: $2.13430357 /(0+2.13430357)=$ The best alternative there which has the biggest preference is PT. SMW with preference value 1 . This is the example of the decision support system for the TOPSIS Method 


\section{DISCUSSION}

According to calculations using the TOPSIS method the results obtained are ranked among the alternatives. First rank is PT.SMW, second rank is PT.SBL, Third rank is Trimulia Kencana Baja, Last Raking is Bos Baja.

\section{CONCLUSION}

1. With the assessment of companies, they are getting bolder in choosing suppliers.

2. By using a decision support system / application system to minimize errors in supplier selection.

3. The TOPSIS method is able to support supplier selection decisions by ranking. 


\section{REFERENCES}

[1] Daniawan, B. (2017). Evaluasi Hasil Kinerja Pengajaran Dosen Menggunakan Metode Topsis. Jurnal Sains Terapan dan Teknologi .

[2] Chamid, A. A. (2016). Penerapan Metode Topsis untuk menentukan prioritas kondisi rumah. Simetris .

[3] Marsono, A. F. (2015). Sistem Pendukung Keputusan Pemilihan Menu Makanan Pada Penderita Obesitas dengan Metode Topsis. Jurnal ilmiah Saintikom .

[4] Riki, R., \& Giap, Y. C. (2018). Design of Acceptance Decision Support System for New Employees in the Technician Position Using AHP and TOPSIS Methods at CV. Techindo Global Solution. bit-Tech, 1(2), 21-29.

[5] Mulyanto, A. (2009). Sistem Informasi Konsep \& Aplikasi. Yogyakarta: Pustaka Pelajar.

[6] Shahroudi, K. a. (2012). Using a Multi-Criteria Decision Making Approach (ANP-TOPSIS) to Evaluate Supplier in iran's Industry. International Journal of Applied Operational Research. Vol.2, No.2 , 37-48.

\section{BIOGRAPHY}

Kelvin Tri Tama (First Author) Born on September 25, 1997, Tangerang, Banten. And students at the University Buddhi Dharma

Andi Leo S.Kom,. M.Kom (Second Author) obtained his Bachelor of Computer degree at Bina Nusantara University in 1989. And earned his Masters of Computer at Bunda Mulia University in 2004 